\title{
Investigation of Buildings in Alaçatı in Terms of Energy Efficiency in Architecture
}

\author{
Ali Berkay Avcı ${ }^{1}$, Şefika Gülin Beyhan ${ }^{2} \odot$ \\ ${ }^{1}$ Research Assistant, Faculty of Architecture, İzmir Institute of Technology, İzmir, Turkey. (Principal contact for editorial \\ correspondence.) Email: aliberkayavci@gmail.com \\ ${ }^{2}$ Professor Doctor, Faculty of Architecture, Süleyman Demirel University, Isparta, Turkey. Email: gulinbeyhan@sdu.edu.tr
}

\begin{abstract}
Purpose

Due to the depletion of natural resources, energy efficiency in buildings has increasingly gained a major priority. As vernacular houses contain accumulated knowledge to adapt to the climate, they have been crucial examples of energy-efficient architecture for the designers. In this manner, the study focuses on Alaçatı vernacular houses. The purpose of the study is to investigate and compare the energy-efficient architecture properties of different types of tourism accommodation buildings.

Design/Methodology/Approach

The accommodation buildings are grouped into three categories, namely "Accommodation buildings converted from vernacular houses of the area", "New accommodation buildings designed in the style of vernacular houses", and "Accommodation buildings that have different architectural styles". Selected three sample buildings from each group are evaluated by energy efficiency principles. Building energy simulation models of the nine case buildings in total are developed to determine the building components' contribution to energy consumption by heating and cooling. The values from energy modeling are used to compare the buildings according to the checklist.

\section{Findings}

According to the results of the study, the density of space, natural ventilation, shading elements, and pitched roof type specialties of vernacular buildings reduce heating and cooling load. However, traditional stone load-bearing walls and bay windows, which are the most significant element of the building form, increase the annual energy demand. At the end of the study, Alaçatı Energy-Efficient Architecture Database Schema is presented in Table 10 as the outcome of the study.

\section{Research Limitations/Implications}

The evaluation of the case buildings merely depends on the annual cooling and heating energy loads of nine randomly selected buildings.

\section{Practical and Social Implications}

The assessment method used in the study provides the opportunity to identify the proportion of the effect of energy efficiency properties on the total heating and cooling load. Furthermore, the "Alaçatı Energy-Efficient Architecture Schema" presented as the ultimate product of this study is expected to guide the architects to design energy-efficient accommodation buildings, without compromising the vernacular architectural appearance of Alaçatı.
\end{abstract}

Originality/Value

The study focuses on the separate effects of the properties of Alaçatı vernacular architecture, instead of focusing on one property, or comparing case buildings on the energy consumption.

Keywords: Energy efficiency, sustainable architecture, climate responsivity, Alaçatl, vernacular architecture 


\section{INTRODUCTION}

Tourism is one of the crucial economic sectors of countries and creates a potential for the welfare and development of society. Because of its diversification and expansion, tourism has become the world's largest and fastest-growing sector in the last 60 years. Especially, due to its contribution to the job creation power and the gross domestic product, the cities based on the tourism sector have been subjected to rapid growth and change. If the correct decisions and precautions are not taken immediately, this rapid growth and change may lead to an imbalance between the "people - nature - tourism area" (Lane, 1994).

Alaçatı district of Çeşme is one of the tourism centers that have been subjected to a rapid change in terms of economic, social, and ecological perspectives. As a former small agricultural village, Alaçatı became one of the popular tourism centers of Turkey, after the publicity of cultural attributions, authentic architecture, and the shores available for windsurfing in the 1990s (Gezgin, 2007). Following the investments and tourism plans made in the 2000s, increasing tourism demand led to the need for accommodation buildings. The vernacular houses of Alaçatı were converted into hotels, and new accommodation buildings were constructed, in order to meet the accommodation needs (İnce, 2013).

In Alaçatı, the energy demand by constructions and the consequent damage to the environment continues increasing day by day. The balance between comfort requirements and damage to the environment in accommodation buildings depends on the integration of energy efficiency principles in building designs. In this context, energy-efficient architecture features of the accommodation buildings with different architectural styles in Alaçatı are the focus of the present study.

In recent years, significant numbers of researches have highlighted the importance of energy-efficient features in vernacular architecture (Eyüce, 2007; Koca, 2019; Liu et al., 2010; Rasulo, 2003; Singh et al., 2009). The research methods in this area have shifted towards the use of building energy modeling software to evaluate the energy efficiency features of vernacular dwellings (Alzoubi \& Almalkawi, 2019; Bencheikh \& Bederina, 2020; Gou et al., 2015; Meiting \& Linxue, 2019; Michael et al., 2017; Mohammadi et al., 2017). Since Alaçatı is a district with vernacular buildings and new buildings that contain the features of vernacular architecture, it is a unique case study area to test the alleged idea in these studies that "vernacular buildings and their design principles are always sustainable". According to that, the energy efficiency features of the accommodation buildings in different architectural styles and forms in Alaçatı constitute the scope of the study. The purpose of the study is to identify and to compare these specialties of the accommodation buildings in different architectural styles. In order to make a convenient evaluation, building energy modeling is employed in the study. The study aims to generate design guidelines based on the empirical results for the future buildings to be designed in Alaçatı. 


\section{LITERATURE REVIEW}

Energy consumption of buildings comprises $40 \%$ of the total energy consumption in the world (Alanne et al., 2010). This ratio denotes the possible role of the buildings in the sustainability of natural resources in energy production. Therefore, reducing the energy consumption of buildings has been among the primary objectives of the developed countries, in terms of economic and ecological balance, and sustainability of the natural sources (Santamouris et al., 2001). Awareness of sustainable architecture and energy efficiency in buildings is inevitable to maintain the balance between culture - economy ecology in all around the world (Bodach et al., 2014).

Even though sustainable architecture is discussed and subjected as a purpose in practice, its extent has not been identified exactly, and it lacks a definition (Baweja, 2014). Over the years, sustainability in architecture has been called by environmental design, green architecture, climate-responsive architecture, ecological architecture, eco-friendly architecture, intelligent architecture, energy-efficient design, and energy responsive-architecture. However, the implementation of sustainable architecture in the last decade can be considered in three groups, namely 1) eco-centric, 2) eco-technic and 3) eco-social (Durmuş Arsan, 2008).

Eco-centric understanding alleges the idea that the buildings have negative effects on the environment. This approach offers that sustainable architecture aims to lower the negative effects of the buildings by the consumption of sources (Eyüce, 2007). On the contrary of eco-centric understanding, the eco-technic approach claims that the structures are interventions on the environment. It defends the idea that the buildings can be designed in harmony with the environment by using technological developments, thus they can have positive effects on nature (Durmuş Arsan, 2003). Eco-social understanding puts people at the center of architecture. It proposes that buildings should be designed concerning cultural and historical values in a way that supports and improves the social life, cultural values, and health of humanity (GhaffarianHoseini et al., 2013).

Sustainable architecture has evolved as a mixture of these understandings, goals, and concerns mentioned above, and gained a general definition. It refers to a climate-responsive, energy-efficient, respectful act on the social and cultural life of the place, and a sense of building design that has minimal impacts on natural resources, economic, green and ecosystems (Bennetts et al., 2003). Sustainable architecture adopts the goal of reducing the consumption and continuation of resources while improving the quality of human life by ecological and technologic approaches. Within this broad definition of sustainable architecture, the present study focuses on the energy efficiency strategies of the vernacular houses in Alaçatı. 
Several studies have evaluated the energy efficiency strategies of vernacular buildings without utilizing an energy modeling software, simply by listing these features. Anna-Maria (2009) inspected the energy efficiency properties of the vernacular houses of Sernikaki, a Greek settlement. In the study, the detection of the orientation to the wind and sun, positioning, ventilation strategy, openings, building envelope, and material properties of the houses were introduced. It was suggested that these architectural specialties should be utilized as a guide for the new houses designed in the region. Manzano-Agugliaro et al. (2015) viewed the energy efficiency specialties of vernacular architecture of the world's climatic regions. Distinct climate areas possess distinct types of architectural design, spatial organization, and planning. The study drew attention to the acquisition of energy efficiency principles that would result in a comfortable indoor environment and less energy demand by the buildings. Dili et al. (2010) appraised the energy efficiency features of the vernacular architecture of Kerala. It was suggested that the use of modularity in architectural design, internal open courtyards, proportions, scale, exterior open spaces, building orientation, and local materials results in achieving a comfortable indoor environment while saving energy. The study proposed that these energy efficiency features of vernacular houses in Kerala can be applied in modern houses in similar climatic regions. Fernandes and Mateus (2012) presented the energy efficiency properties of multiple types of Portuguese vernacular houses. Concerning the adaptation to the climate of the region, various strategies were implemented in the vernacular houses in the area. These passive design strategies were the organization of the placement of the houses in the villages, promotion of natural ventilation, reducing the solar gains in summer, capturing solar gains in winter, reducing heat transfer through the building components, and provide efficient management of sources. Even though these studies evaluated the energy efficiency features to a broader extent, they lacked providing the empirical equivalents of these strategies as they did not use any energy modeling software.

The studies in the area of sustainable features of vernacular architecture have a trend towards quantitative research methods lately. According to Nguyen et al. (2019), starting from the year of 2011, quantitative research methods use rate increased by $8.4 \%$, while qualitative research methods use rate decreased by $16.6 \%$, comparing to the studies on sustainable features of vernacular architecture between 1986 and 2010. These studies aim to evaluate the vernacular houses by calculating heating and cooling load demands. Alzoubi and Almalkawi (2019) compared the vernacular and contemporary dwellings in Northern Jordan by thermal comfort and energy consumption performance. Energy modeling results of 2 types of vernacular and 2 types of contemporary house units were presented in the study. According to the energy modeling results, the vernacular houses provide a more 
comfortable indoor thermal environment, along with less amount of energy demand in winter and summer seasons. Michael et al. (2017) investigated the effect of natural ventilation on the interior thermal environment in the residential vernacular architecture of Cyprus. The study included different ventilation strategies during the summer period, so as to find the proper ventilation regime to achieve minimum cooling load. It was confirmed that natural ventilation has a positive contribution to the cooling in the vernacular architecture in Cyprus. Meiting and Linxue (2019) explored the differences between the traditional and contemporary dwellings of Zhejiang in terms of climate adaptability. The outcomes of the study suggested that the use of interior circulations like corridors and patios improves the thermal environment inside the houses. Along with that, the courtyards of the traditional houses with the use of natural stone material lower the energy demand in winter and summer. Bencheikh and Bederina (2020) compared the thermal performances and energy demand of a vernacular and a contemporary house in Laghouat, Algeria by energy simulation. The results of the study showed that the vernacular house reduces the energy demand by $39 \%$ and performs a more comfortable interior thermal environment. Mohammadi et al. (2017) revealed the effects of the use of vernacular climatic strategies of vernacular houses in Bushehr, Iran, in common residential buildings in the same region. In the study three energy models of the same case study house were created, which are the base model and improved models with the additions of the vernacular strategies. The results of the study showed that two improved models reduced the energy demand by $16 \%$ and $\% 26$, in comparison with the base model. Gou et al. (2015) investigated the vernacular energy efficiency strategies used by vernacular dwellings in the summer and winter seasons of China. It was revealed that these houses were powerful in adapting to the local climatic conditions and lowers the cooling load demand in the summer season.

These studies employed building energy modeling to evaluate the energy efficiency features of vernacular architecture in various regions and focused on the comparisons of overall energy demand. However, the separate effects of the vernacular architecture properties on the overall energy consumption were not investigated by any of these researches. Therefore, the present study goes further to fill this gap by using building energy modeling to reveal the effects of each energy efficiency specialty of Alaçatı houses respectively on the energy demand by heating and cooling. The case studies investigated in the study consist of three groups of accommodation buildings in Alaçatı. These are the accommodation buildings converted from vernacular houses of the area, the new accommodation buildings designed in the style of vernacular houses and the accommodation buildings with different architectural styles in Alaçatı. It is aimed to present if the architectural properties of the vernacular houses are truly energy-efficient when they are implemented in the new building designs. 


\section{METHODOLOGY}

The main purpose of the research is to assess the accommodation buildings in Alaçatı in terms of building energy efficiency. According to this aim, the energy-efficient architecture features of different types of tourism accommodation buildings in Alaçatı are viewed in three categories:

- $1^{\text {st }}$ Group: The accommodation buildings converted from vernacular houses of the area

- $2^{\text {nd }}$ Group: The new accommodation buildings designed in the style of vernacular houses

- $3^{\text {rd }}$ Group: The accommodation buildings with different architectural styles

These categories are separated from each other in terms of their architectural features in the construction and façade specialties. The accommodation buildings in the $1^{\text {st }}$ group are located in the historical center of Alaçatı. They are the major buildings that create the authenticity and the tourism appeal of the traditional texture of Alaçatı. Regarding this, they have been an example of the new accommodation buildings in the area. The accommodation buildings in the $2^{\text {nd }}$ group have the highest number in the area among the three groups of buildings. These buildings are located together around the historical center of Alaçatı with the buildings in the 1st Group. Therefore, they were designed by adopting the characteristics of Alaçatı's traditional architecture in order to comply with the traditional texture. The accommodation buildings of the $3^{\text {rd }}$ Group are located in the northern part of the town. They do not carry the vernacular architectural specialties and have various styles in terms of façade appearance and building structure. In the study, the case buildings are chosen evenly among these three groups, as they are explicitly differentiated from each other.

The method of the study is based on an evaluation checklist, which is constructed from the literature review part of the study by the proper energy-efficient architecture features for the Alaçatı region. The evaluation checklist contains the following criteria:

- Building form,

- Shading strategy,

- Natural ventilation,

- The density of space,

- Building materials,

- Roof style.

To compare the effects of each criterion in the checklist, three case buildings from each group were selected for the study (Nine buildings in total). The case buildings were chosen according to make certain that they present different orientations, locations, densities of spaces, and form specialties for each group. The architectural floor plans of the case 
Investigation of Buildings in Alaçatı in Terms of Energy Efficiency in Architecture

buildings were presented respecting the groups in Table 1 respectively to the three different categories.

Table 1. Plans of the case buildings (Balbay, 2017; Çelik, 2010; KGCArchitecture, 2017; Seymen, 2010)

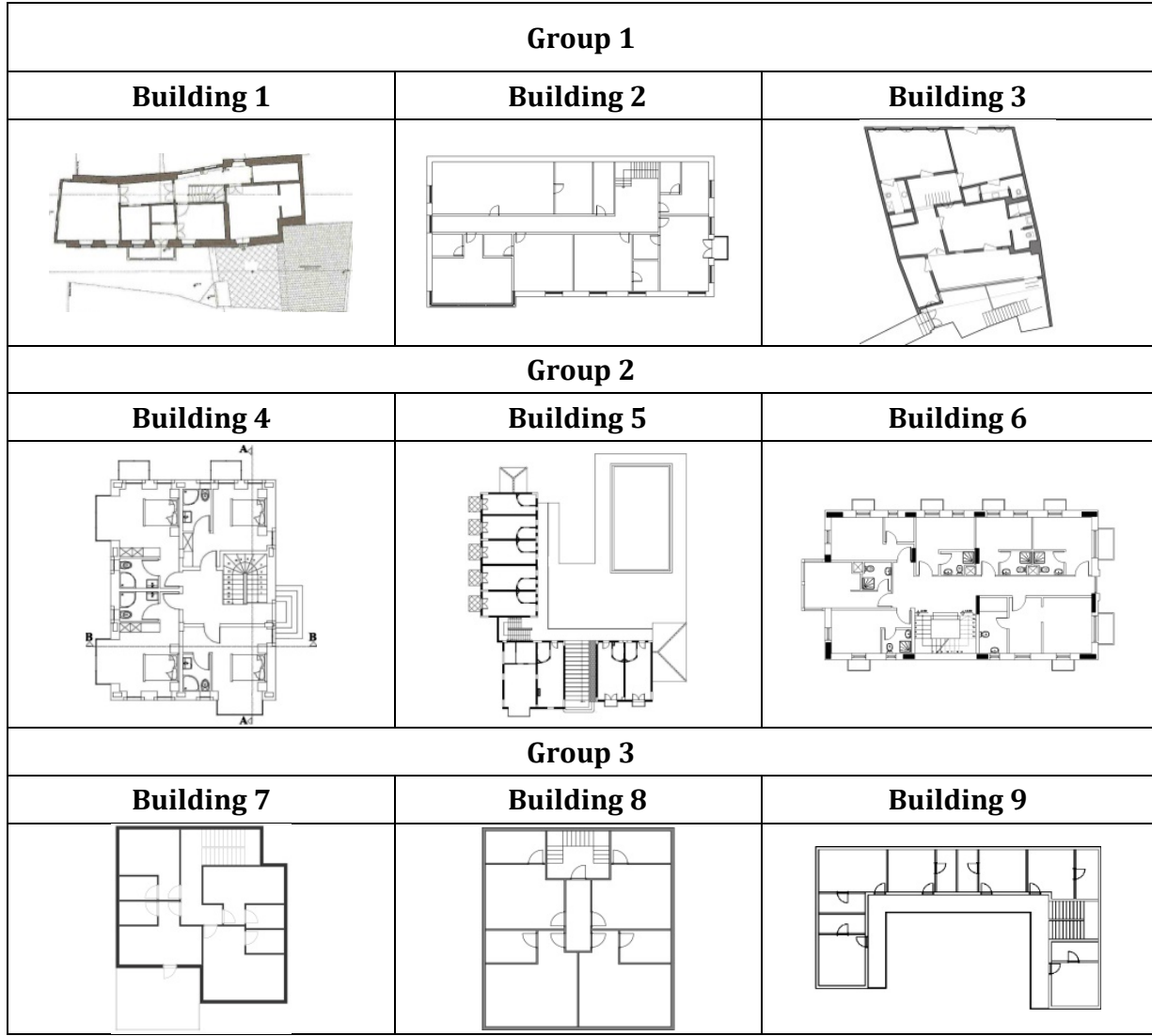

The façade photographs of each building were given respectively to the building groups in Table 2 .

Table 2. Façades photographs of the case buildings

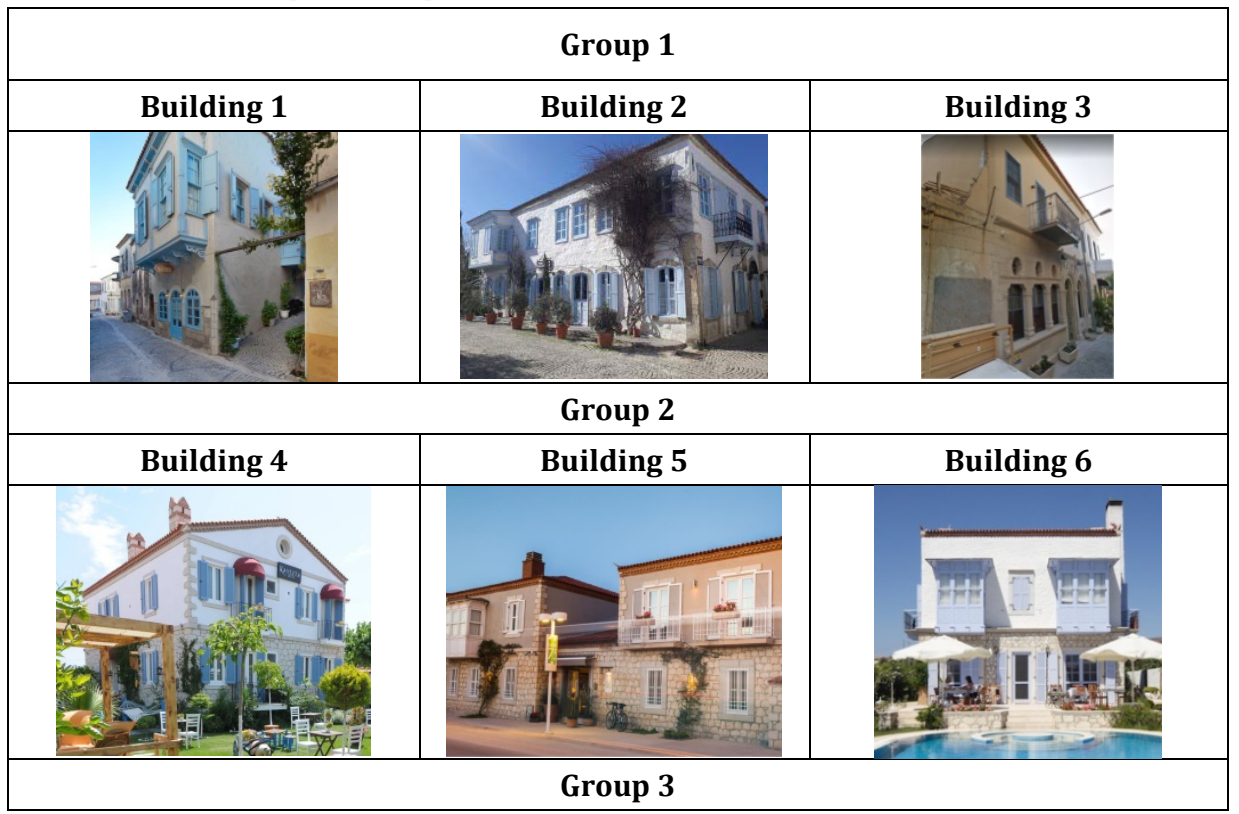




\begin{tabular}{|c|c|c|}
\hline Building 7 & Building 8 & Building 9 \\
\hline & & \\
\hline
\end{tabular}

The energy models of the nine case buildings were done in the Design Builder Program, which uses the Energy Plus Software database. The photo of the energy model of Building 1 was presented as an example in Figure 1.

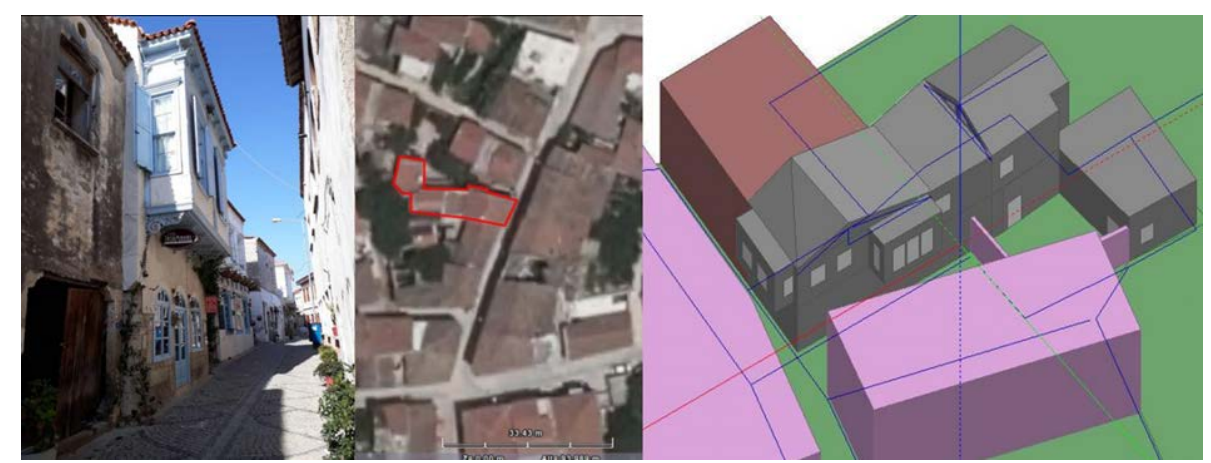

Building user schedules, construction materials, and climate data were included in the energy models, to provide accurate energy simulations (Energy Plus, 2017). Building user schedules data were obtained by the survey with the occupants of the accommodation buildings. The building materials were defined by respecting the different building components of each building. The building material information of the case buildings was provided by the application projects and restoration drawings, which were taken from the archives of the designer offices and hotel administrations (Balbay, 2017; KGCArchitecture, 2017; Seymen, 2017). Air conditioning units were introduced in the buildings to measure the cooling load, while natural gas heating units were located for heating measurements. The space heating setback values were defined as $20^{\circ} \mathrm{C}$ for heating and $26^{\circ} \mathrm{C}$ for cooling in the models in compliance with the ASHRAE Standard 209 (Scott West et al., 2019). The evaluation of the study was limited to heating and cooling energy consumption values in kilowatt-hour (kWh).

In order to determine the effects of the checklist criteria on the building energy model, firstly the current energy demands of the buildings were taken as a "control model". Later the models were altered according to the criteria, namely "modified model". The difference between the energy consumption values of the control models and modified models corresponded to the effects of the criteria, which is called "the effect value" (Figure 2).
Figure 1. Photo, satellite view and energy model of the Building 1 (Google Earth, 2017) 
Figure 2. The procedure of finding the building components' effects on the energy demand

Figure 3. Air temperature values of Alaçatı (Climate: Alaçatı, 2017)

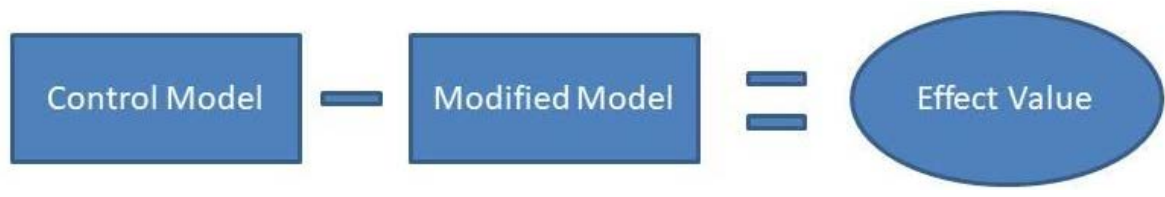

As an instance, to find the effect of a shading element on the cooling and heating load of a case building, the energy model is modified by removing the shading element. The difference in the energy demands of these two models represents the effect of the shading element on the cooling and heating load in $\mathrm{kWh}$. As in this example, these phases were applied to all checklist criteria of the study.

\section{Climate of Alaçatı}

Alaçatı is located on the west coast of İzmir, Turkey. It shows the characteristics of the Mediterranean climate under the influence of the Aegean Sea breezes. According to Köppen Climate Classification, Alaçatı is under the 'Csa' section, which refers to the hot and temperate climatic region (Rubel \& Kottek, 2010). The average air temperature varies between $15^{\circ} \mathrm{C}-38^{\circ} \mathrm{C}$ in summer days, while in the winter days it changes between $-2^{\circ} \mathrm{C}-16^{\circ} \mathrm{C}$ (Figures 3 and 4). Heat gain by direct sun radiation varies between hourly $650 \mathrm{Wh} / \mathrm{m} 2$ and $110 \mathrm{Wh} / \mathrm{m} 2$ in a day. Mean relative humidity in a month is $50 \%$, while in the winter days it is $70 \%$. The prevailing wind direction is north-west with an average speed of $5 \mathrm{~m} / \mathrm{s}$. It annually blows 300 days on average. The consistent winds from the south and north directions together with the breezes from the Alaçatı Bay create possibilities for passive cooling by natural ventilation techniques (Climate: Alaçatı, 2017; Energy Plus, 2017; Terim, 2011).

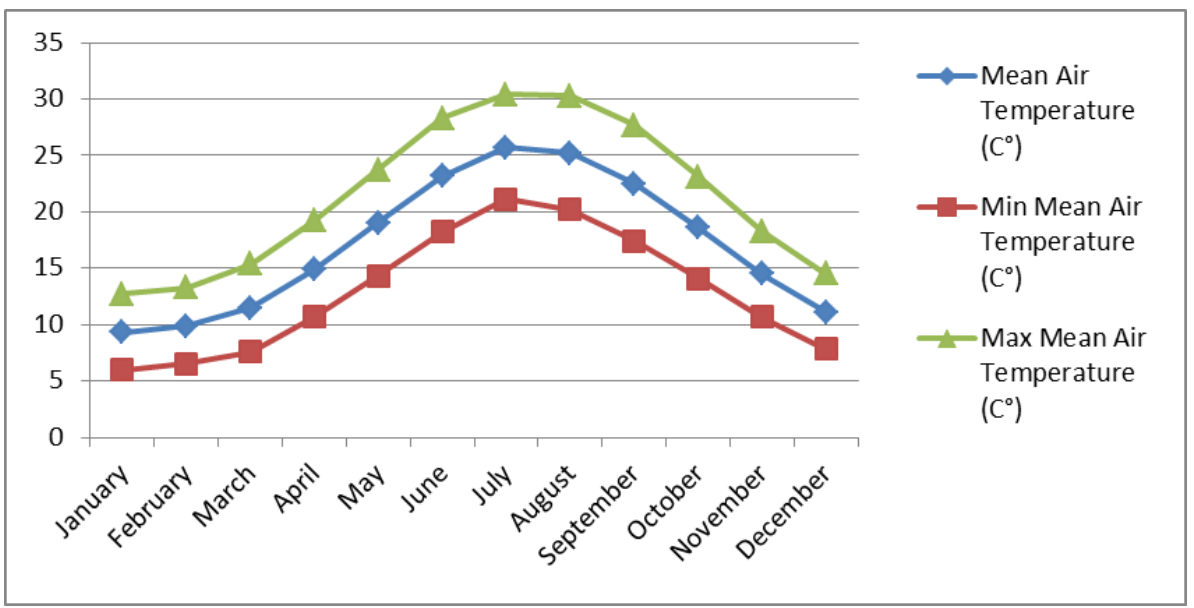




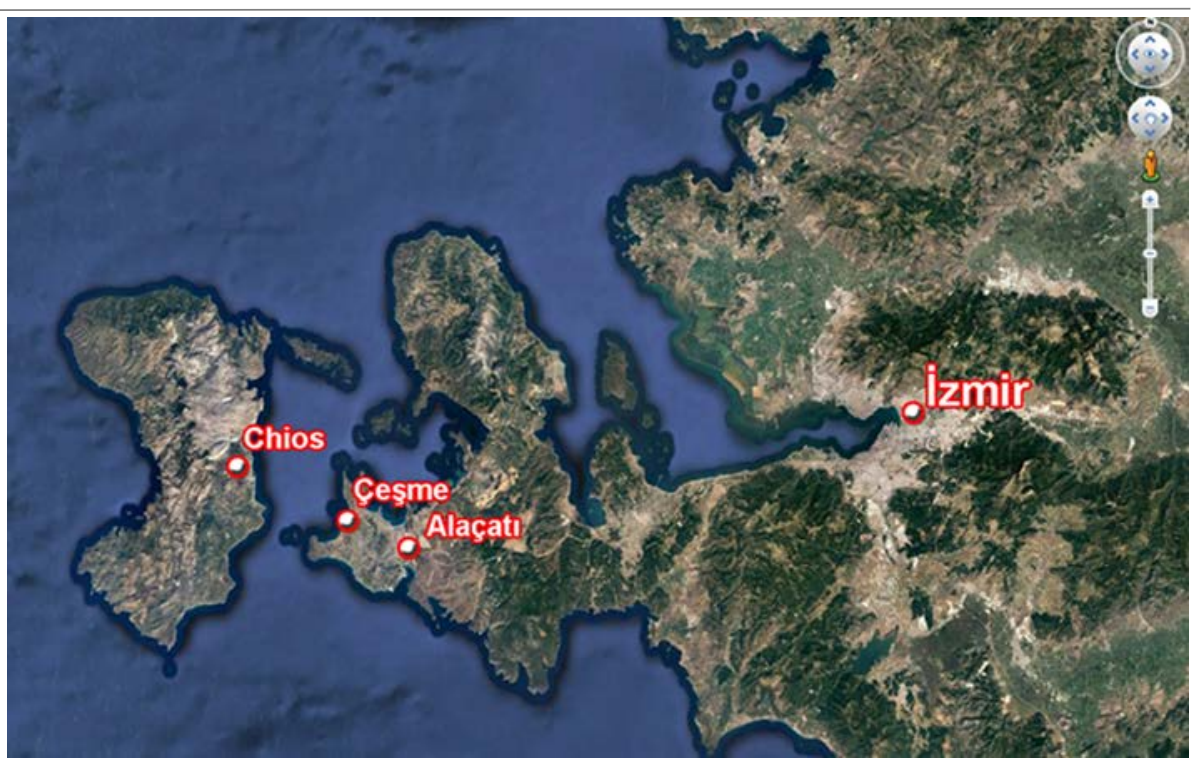

\section{Research Limitations}

The evaluation of the buildings merely depends on the effects of the structural components of the case buildings on the annual cooling and heating energy demand. The architectural specialties of Alaçatı vernacular houses are not assessed in terms of their originality or coherence to the conservational quality. The study is limited to 9 randomly selected buildings, and all the case buildings are assumed to be using air conditioning units for cooling and gas-fuelled heating units for heating purposes. Since the building energy models employ the weather data of İzmir, which is provided by Adnan Menderes Weather Station, the outcomes of the research are only valid and applicable to the climatic region of Alaçatı.

\section{DISCUSSION OF RESULTS}

The results of the assessment are presented in this section according to the checklist of energy efficiency in architecture. The effects of the specific criterion on the annual building energy demand by cooling and heating are included in the tables respectively to the nine case buildings.

\section{Building Form}

The case buildings have various forms such as rectangular prism, square, "L" and "C" shapes. It is seen that the building forms tend to protect the most occupied spaces from the direct sun exposure in summer and the prevailing winds in winter. Only in the accommodation buildings from Group 1 and Group 2 contain extensions such as bay windows and balconies. Bay windows carry the potential to work as sunspace in winter and provide shading in summer. They are the most significant components of the vernacular buildings of Alaçatı and have the availability to play a role in energy efficiency (Figure 5).
Figure 4. Location of Alaçatı (Google Earth, 2018) 
Figure 5. Bay window of Building 2

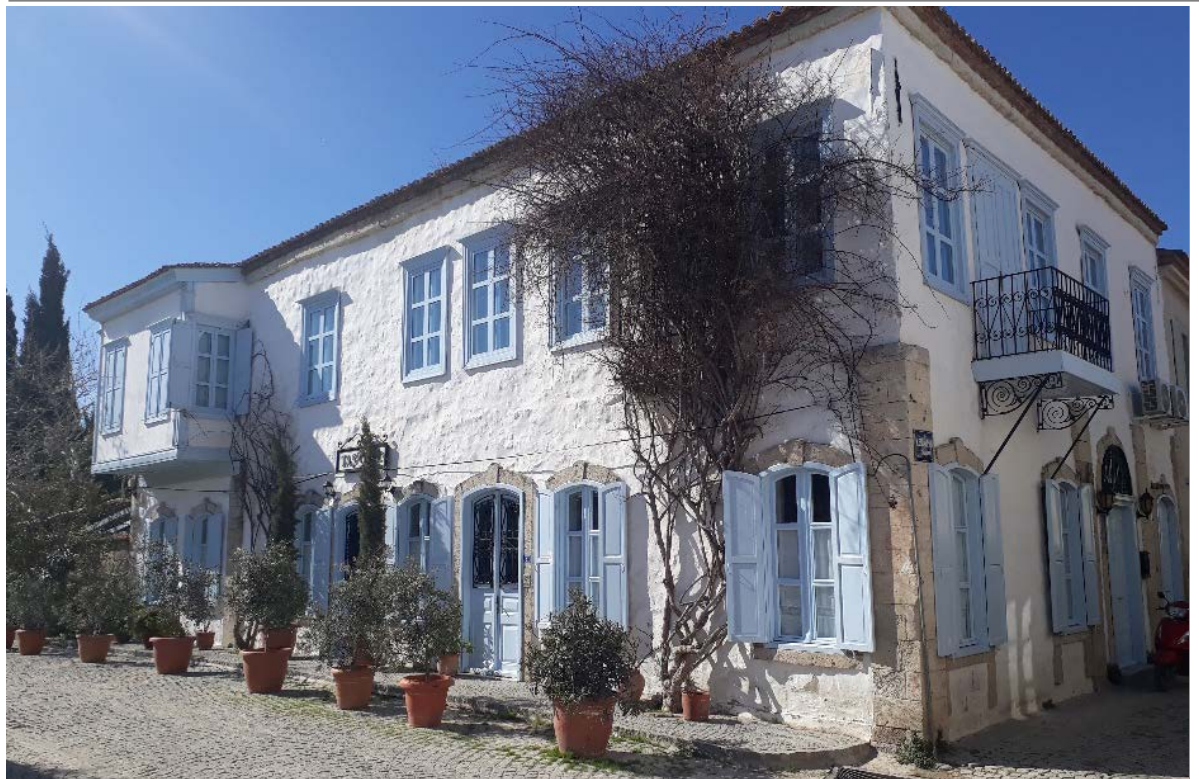

However, in the study, it was seen that the bay windows increase the heating load in winter up to $11.4 \%$, while they do not have a significant effect in summer according to the simulation results. The reason for this result is that these components widen the area that loses heat to the outside, and they are not located in the correct facades (Table 3). It would be more energy-efficient to utilize bay windows on the south façades with interior separations in the climate of Alaçatı. In that case, the bay windows can be used as a sunspace, which can be isolated in winter to work as a buffer zone to lower the heat transfer rate. In the summer period, the separation and the windows of the bay windows need to be opened to create cross ventilation through the building. Balconies and other extensions also need to be in the south façades, as the angle of the sun can be controlled easily in this direction in both winter and summer.

Table 3. The effect of bay windows on energy consumption

\begin{tabular}{|c|c|c|}
\hline \multicolumn{3}{|c|}{ Group 1} \\
\hline Building 1 & Building 2 & Building 3 \\
\hline $\begin{array}{l}\text { Heating: }+5.3 \% \\
\text { Cooling: }-0.2 \% \\
\text { Total: }+3.1 \% \\
\end{array}$ & $\begin{array}{l}\text { Heating: }+8.4 \% \\
\text { Cooling: }+2.5 \% \\
\text { Total: }+5 \%\end{array}$ & There are no bay windows \\
\hline \multicolumn{3}{|c|}{ Group 2} \\
\hline Building 4 & Building 5 & Building 6 \\
\hline $\begin{array}{l}\text { Heating: }+6.7 \% \\
\text { Cooling: }-3.4 \% \\
\text { Total: }+1.8 \% \\
\end{array}$ & $\begin{array}{l}\text { Heating: }+1 \% \\
\text { Cooling: }+0.5 \% \\
\text { Total: }+0.8 \% \\
\end{array}$ & $\begin{array}{l}\text { Heating: }+11.4 \% \\
\text { Cooling: }-2.3 \% \\
\text { Total: }+4 \% \\
\end{array}$ \\
\hline \multicolumn{3}{|c|}{ Group 3} \\
\hline Building 7 & Building 8 & Building 9 \\
\hline There are no bay windows & $\begin{array}{l}\text { There are no bay } \\
\text { windows }\end{array}$ & There are no bay windows \\
\hline
\end{tabular}




\section{Shading Strategy}

Shading strategy is an eminent factor for all the buildings in Alaçatı, as avoiding the direct sun in the prolonged summer period lowers the cooling energy demand crucially. The buildings in Group 1 are under the shading effect of the neighbor buildings, while the others are exposed to the sun during the day, except the case of Building 8. Among all case buildings, only number 8 and 9 have adjustable shading devices on the windows, while the others do not have such shading devices. In order to see the effect of the shading elements in the energy models, shading devices were added to all buildings and compared with the model versions that do not have shading elements. According to the results, the shading devices reduce the cooling load in summer by $29 \%$ to $3 \%$ in the buildings depending on the window area and orientations (Table 4).

Table 4. The effect of shading devices on energy consumption.

\begin{tabular}{|c|c|c|}
\hline \multicolumn{3}{|c|}{ Group 1} \\
\hline Building 1 & Building 2 & Building 3 \\
\hline $\begin{array}{l}\text { Heating: }+2 \% \\
\text { Cooling: }-3 \% \\
\text { Total: }+0.1 \% \\
\end{array}$ & $\begin{array}{l}\text { Heating: }+15 \% \\
\text { Cooling: }-16 \% \\
\text { Total: }-2 \% \\
\end{array}$ & $\begin{array}{l}\text { Heating: }+3 \% \\
\text { Cooling: }-8 \% \\
\text { Total: }+0.8 \% \\
\end{array}$ \\
\hline \multicolumn{3}{|c|}{ Group 2} \\
\hline Building 4 & Building 5 & Building 6 \\
\hline $\begin{array}{l}\text { Heating: }+11 \% \\
\text { Cooling: }-13 \% \\
\text { Total: }-1 \% \\
\end{array}$ & $\begin{array}{l}\text { Heating: }+1.8 \% \\
\text { Cooling: }-8 \% \\
\text { Total: }-1.2 \% \\
\end{array}$ & $\begin{array}{l}\text { Heating: }+15.5 \% \\
\text { Cooling: }-15.8 \% \\
\text { Total: }-1.3 \% \\
\end{array}$ \\
\hline \multicolumn{3}{|c|}{ Group 3} \\
\hline Building 7 & Building 8 & Building 9 \\
\hline $\begin{array}{l}\text { Heating: } 0 \% \\
\text { Cooling: }-23 \% \\
\text { Total: }-7 \%\end{array}$ & $\begin{array}{l}\text { Heating: } 0 \% \\
\text { Cooling: }-29 \% \\
\text { Total: }-7 \%\end{array}$ & $\begin{array}{l}\text { Heating: } 0 \% \\
\text { Cooling: }-26.2 \% \\
\text { Total: }-6,3 \%\end{array}$ \\
\hline
\end{tabular}

The buildings with wider facades and more windows to the west and south have higher energy efficiency from the shading devices. It was observed that shading elements increase the heating load in winter, as they prevent the heat gains from the sun. According to that, shading devices should be selected operable according to the time of the year.

\section{Natural Ventilation}

Natural ventilation is employed to provide fresh air and climate control in all the case buildings. The effects of natural ventilation in the case buildings are presented in Table 5 . It was seen that natural ventilation has a potent role in reducing cooling energy in summer. In all case buildings, except Building 4, natural ventilation decreases cooling load between $2.8 \%$ and $20 \%$. However, it was detected that natural ventilation does not have any effect on heating load, as it is only utilized to provide fresh air in winter. 
Investigation of Buildings in Alaçatı in Terms of Energy Efficiency in Architecture

Table 5. The effect of natural ventilation on energy consumption

\begin{tabular}{|c|c|c|}
\hline \multicolumn{3}{|c|}{ Group 1} \\
\hline Building 1 & Building 2 & Building 3 \\
\hline $\begin{array}{l}\text { Heating: }+0.3 \% \\
\text { Cooling: }-20 \% \\
\text { Total: }-7.6 \% \\
\end{array}$ & $\begin{array}{l}\text { Heating: }+0,1 \% \\
\text { Cooling: }-7 \% \\
\text { Total: }-4 \% \\
\end{array}$ & $\begin{array}{l}\text { Heating: } 0 \% \\
\text { Cooling: }-5 \% \\
\text { Total: }-2 \% \\
\end{array}$ \\
\hline \multicolumn{3}{|c|}{ Group 2} \\
\hline Building 4 & Building 5 & Building 6 \\
\hline $\begin{array}{l}\text { Heating: } 0 \% \\
\text { Cooling: }+1,2 \% \\
\text { Total: }+1 \% \\
\end{array}$ & $\begin{array}{l}\text { Heating: } 0 \% \\
\text { Cooling: }-6.5 \% \\
\text { Total: }+1 \% \\
\end{array}$ & $\begin{array}{l}\text { Heating: }+0.3 \% \\
\text { Cooling: }-2.8 \% \\
\text { Total: }-1.4 \% \\
\end{array}$ \\
\hline \multicolumn{3}{|c|}{ Group 3} \\
\hline Building 7 & Building 8 & Building 9 \\
\hline $\begin{array}{l}\text { Heating: }+0.9 \% \\
\text { Cooling: }-4.3 \% \\
\text { Total: }-1.3 \% \\
\end{array}$ & $\begin{array}{l}\text { Heating: } 0 \% \\
\text { Cooling: }-3.5 \% \\
\text { Total: }-0.8 \% \\
\end{array}$ & $\begin{array}{l}\text { Heating: } 0 \% \\
\text { Cooling: }-3.6 \% \\
\text { Total: }-0.9 \% \\
\end{array}$ \\
\hline
\end{tabular}

\section{The Density of Space}

The accommodation buildings converted from vernacular houses are located in the high-density texture of the center of Alaçatı. The satellite views of the case buildings are given in Table 6 to present the conditions of the density of space. As it is seen, the case buildings converted from Alaçatı vernacular houses (Buildings 1, 2, and 3) possess high-density neighborhoods. These buildings are adjacent to other buildings from least on one side, and the roads in front of them are narrower. The other case buildings have a low-density neighborhood except Building 7.

Table 6. The satellite views of the case buildings (Google Earth, 2017)

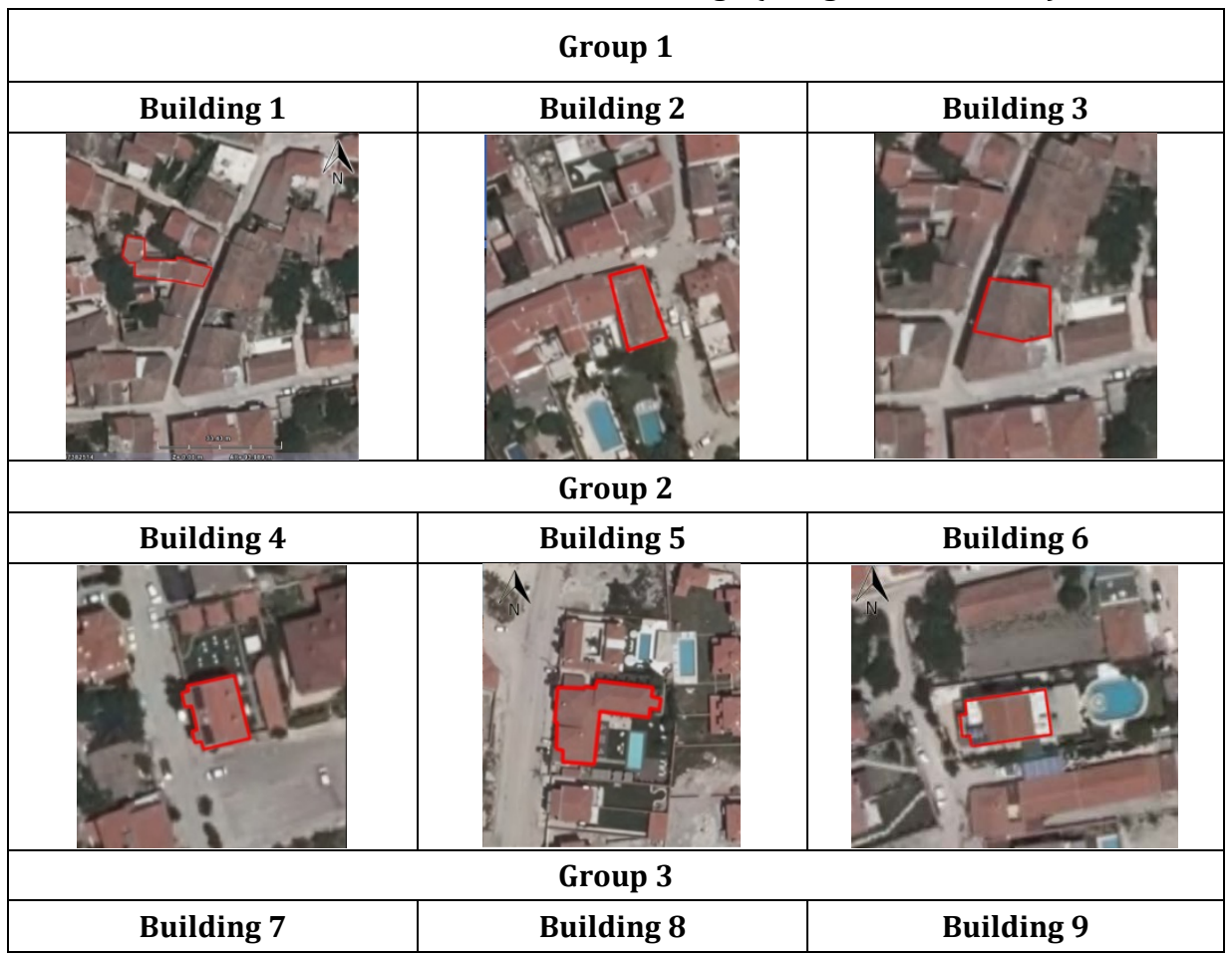




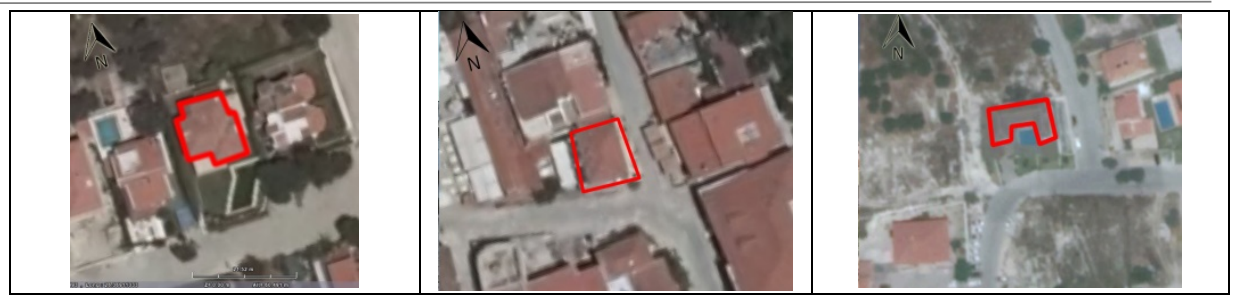

As indicated in Table 7, the relationship between the building and its density of space is crucial in terms of heating and cooling energy consumption. The reason is that high-density neighborhood helps to lower the effect of winds in winter and provides shading in summer. According to the results, Buildings 1, 2, 3, and 8 profit from the reduction of energy consumption by the neighbor buildings, up to $16 \%$ in winter and 53\% in summer. However, the buildings located in a lowdensity neighborhood are not under this effect, as they are exposed to the direct sun light and the consistent winds of Alaçatı.

Table 7. The effect of the density of space on energy consumption

\begin{tabular}{|c|c|c|}
\hline \multicolumn{3}{|c|}{ Group 1} \\
\hline Building 1 & Building 2 & Building 3 \\
\hline $\begin{array}{l}\text { Heating: }-0.8 \% \\
\text { Cooling: }-8.3 \% \\
\text { Total: }-3.7 \% \\
\end{array}$ & $\begin{array}{l}\text { Heating: }+16 \% \\
\text { Cooling: }-20 \% \\
\text { Total: }-19 \% \\
\end{array}$ & $\begin{array}{l}\text { Heating: }-7 \% \\
\text { Cooling: }-53 \% \\
\text { Total: }-21 \% \\
\end{array}$ \\
\hline \multicolumn{3}{|c|}{ Group 2} \\
\hline Building 4 & Building 5 & Building 6 \\
\hline $\begin{array}{l}\text { Heating: } 0 \% \\
\text { Cooling: }-3.2 \% \\
\text { Total: }-1.4 \% \\
\end{array}$ & $\begin{array}{l}\text { The building does not } \\
\text { have any neighborhood } \\
\text { buildings }\end{array}$ & $\begin{array}{l}\text { The building does not have } \\
\text { any neighborhood buildings }\end{array}$ \\
\hline \multicolumn{3}{|c|}{ Group 3} \\
\hline Building 7 & Building 8 & Building 9 \\
\hline $\begin{array}{l}\text { The building does not have } \\
\text { any neighborhood } \\
\text { buildings }\end{array}$ & $\begin{array}{l}\text { Heating: }-4.5 \% \\
\text { Cooling: }-28.5 \% \\
\text { Total: }-38.4 \% \\
\end{array}$ & $\begin{array}{l}\text { The building does not have } \\
\text { any neighborhood buildings }\end{array}$ \\
\hline
\end{tabular}

\section{Building Materials}

Natural stone load-bearing walls are one of the very significant construction specialties of the accommodation buildings converted from vernacular houses of Alaçatı. It was observed that natural stone loadbearing walls in the buildings in Group 1 increase heating and cooling load comparing to insulated brick walls in the other building groups. The reason for this is the porosity of the natural stone that enhances air leakage. Therefore, heating or cooling the interior air requires more energy. On the other hand, the insulated walls show a positive performance between $7.6 \%$ and $21 \%$ in terms of decreasing overall annual energy demand (Table 8). 
Investigation of Buildings in Alaçatı in Terms of Energy Efficiency in Architecture

Table 8. The effect of building materials on energy consumption

\begin{tabular}{|c|c|c|}
\hline \multicolumn{3}{|c|}{ Group 1} \\
\hline Building 1 & Building 2 & Building 3 \\
\hline $\begin{array}{l}\text { Heating: }+2,6 \% \\
\text { Cooling: }-1.1 \% \\
\text { Total: }-1.2 \% \\
\end{array}$ & $\begin{array}{l}\text { Heating: }+7 \% \\
\text { Cooling: }+1.5 \% \\
\text { Total: }+4 \% \\
\end{array}$ & $\begin{array}{l}\text { Heating: }+8 \% \\
\text { Cooling: }+1.5 \% \\
\text { Total: }+6 \% \\
\end{array}$ \\
\hline \multicolumn{3}{|c|}{ Group 2} \\
\hline Building 4 & Building 5 & Building 6 \\
\hline $\begin{array}{l}\text { Heating: }-37 \% \\
\text { Cooling: }-4.7 \% \\
\text { Total: }-21.4 \% \\
\end{array}$ & $\begin{array}{l}\text { Heating: }-11 \% \\
\text { Cooling: }-5.6 \% \\
\text { Total: }-10 \% \\
\end{array}$ & $\begin{array}{l}\text { Heating: }-14.1 \% \\
\text { Cooling: }-2 \% \\
\text { Total: }-7.6 \% \\
\end{array}$ \\
\hline \multicolumn{3}{|c|}{ Group 3} \\
\hline Building 7 & Building 8 & Building 9 \\
\hline $\begin{array}{l}\text { Heating: }-16 \% \\
\text { Cooling: }-1.1 \% \\
\text { Total: }-10 \% \\
\end{array}$ & $\begin{array}{l}\text { Heating: }-8.3 \% \\
\text { Cooling: }-2.8 \% \\
\text { Total: }-7.9 \% \\
\end{array}$ & $\begin{array}{l}\text { Heating: }-13 \% \\
\text { Cooling: }-4.2 \% \\
\text { Total: }-10.9 \% \\
\end{array}$ \\
\hline
\end{tabular}

\section{Roof Style}

The case buildings in all three groups have gable or pitched roof types with interior wood ceiling applications attached to them. The unoccupied space between the roof and ceiling behaves as a thermal buffer space against the exterior thermal conditions. This unoccupied zone lowers the heat transfer rate in the winter and summer seasons. However, in all case buildings, these buffer spaces prevent passive heat gain by direct sun exposure on the roof in winter, and consequently increase the heating load between $27.6 \%-0.6 \%$. The effects of roof styles of the case buildings are presented in Table 9.

Table 9. The effect of roof style on energy consumption

\begin{tabular}{|c|c|c|}
\hline \multicolumn{3}{|c|}{ Group 1} \\
\hline Building 1 & Building 2 & Building 3 \\
\hline $\begin{array}{l}\text { Heating: }+0.6 \% \\
\text { Cooling: }-6.1 \% \\
\text { Total: }-2 \%\end{array}$ & $\begin{array}{l}\text { Heating: }+2 \% \\
\text { Cooling: }-4 \% \\
\text { Total: }-1 \% \\
\end{array}$ & $\begin{array}{l}\text { Heating: }+8 \% \\
\text { Cooling: }-14 \% \\
\text { Total: }-1.5 \%\end{array}$ \\
\hline \multicolumn{3}{|c|}{ Group 2} \\
\hline Building 4 & Building 5 & Building 6 \\
\hline $\begin{array}{l}\text { Heating: }+5 \% \\
\text { Cooling: }-1.2 \% \\
\text { Total: }-2 \% \\
\end{array}$ & $\begin{array}{l}\text { Heating: }+10 \% \\
\text { Cooling: }-9.4 \% \\
\text { Total: }+6.3 \% \\
\end{array}$ & $\begin{array}{l}\text { Heating: }+16.7 \% \\
\text { Cooling: }-7 \% \\
\text { Total: }+4 \%\end{array}$ \\
\hline \multicolumn{3}{|c|}{ Group 3} \\
\hline Building 7 & Building 8 & Building 9 \\
\hline $\begin{array}{l}\text { Heating: }+27.6 \% \\
\text { Cooling: }-26.6 \% \\
\text { Total: }+5 \%\end{array}$ & $\begin{array}{l}\text { Heating: }+11.6 \% \\
\text { Cooling: }-9.5 \% \\
\text { Total: }+6.6 \%\end{array}$ & $\begin{array}{l}\text { Heating: }+2 \% \\
\text { Cooling: }-7.4 \% \\
\text { Total: }-0.3 \%\end{array}$ \\
\hline
\end{tabular}

\section{Overall Assessment of the Results}

The results of the effects on the energy demand of the checklist criteria were introduced in the previous sections. In this section, the overall results are presented concerning the accommodation building groups (Figures 6, 7, and 8). According to the graphs, the most significant criterion on reducing the total energy demand is the effect of the density 
of space. The most significant impact of the density of space was seen in the cooling load of Building 3 by 53\%. The criterion that reduces the heating load the most is building materials. The effect of the insulated brick walls lowers the heating load by $37 \%$ in Building 4 .

All case buildings carry specialties to reduce the annual cooling load against the hot climate of Alaçatı. However, some criteria increase the heating load while reducing cooling load significantly, such as roof style, shading elements, and bay windows. This situation is visible in the case of Building 7 clearly, as its roof reduces cooling load by $26.6 \%$, while increases heating load in winter by $27.6 \%$.

In terms of building groups, high-density neighborhoods, natural ventilation, and roof style specialties of the accommodation buildings in Group 1 are found more effective in comparison with the other buildings. However, the effect of bay windows and natural stone walls increases the energy demand and creates disadvantages comparing to the other building types.
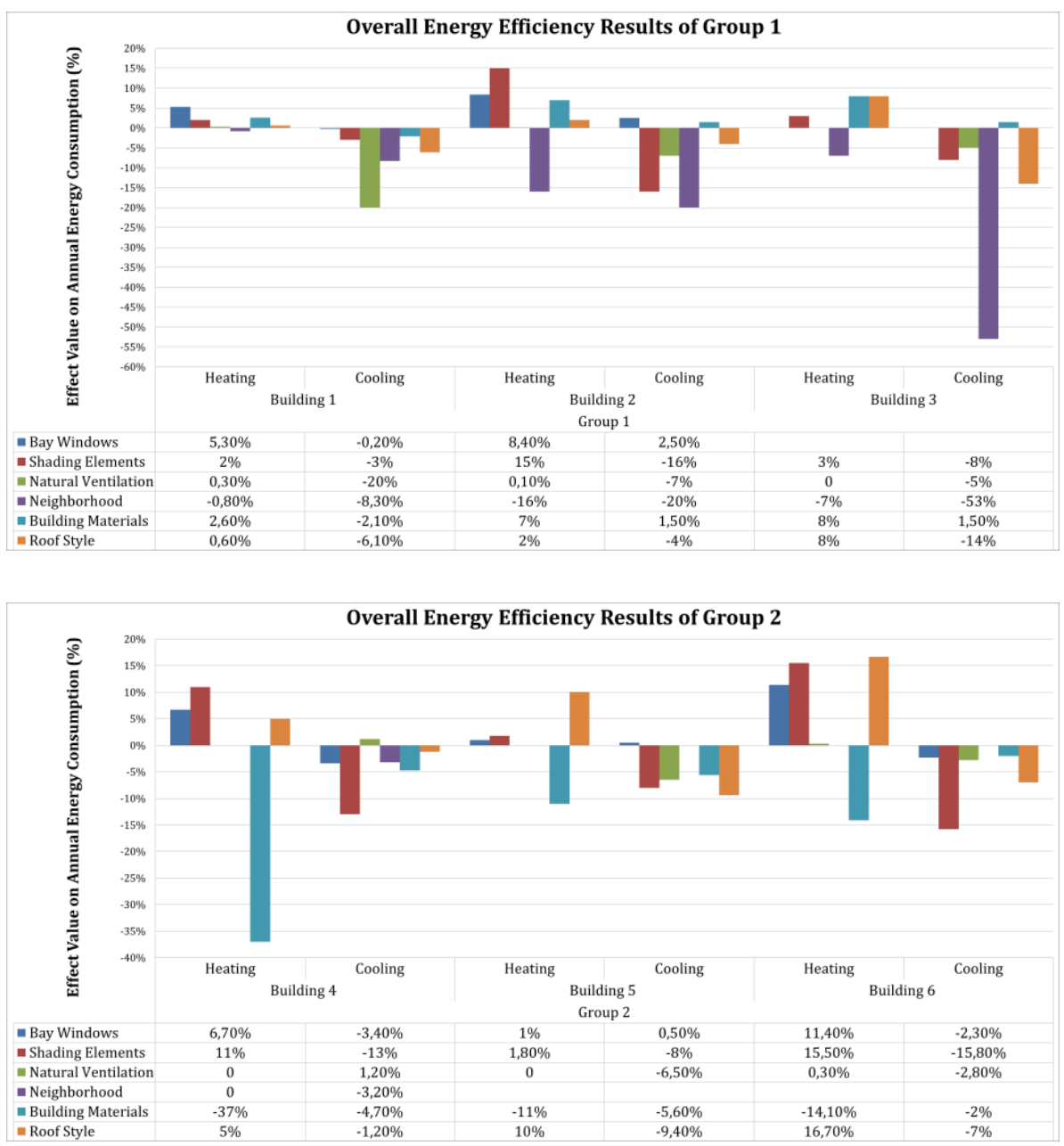

Figure 6. Overall Energy Efficiency Results of Group 1

Figure 7. Overall Energy Efficiency Results of Group 2 
Figure 8, Overall Energy Efficiency Results of Group 3
Investigation of Buildings in Alaçatı in Terms of Energy Efficiency in Architecture

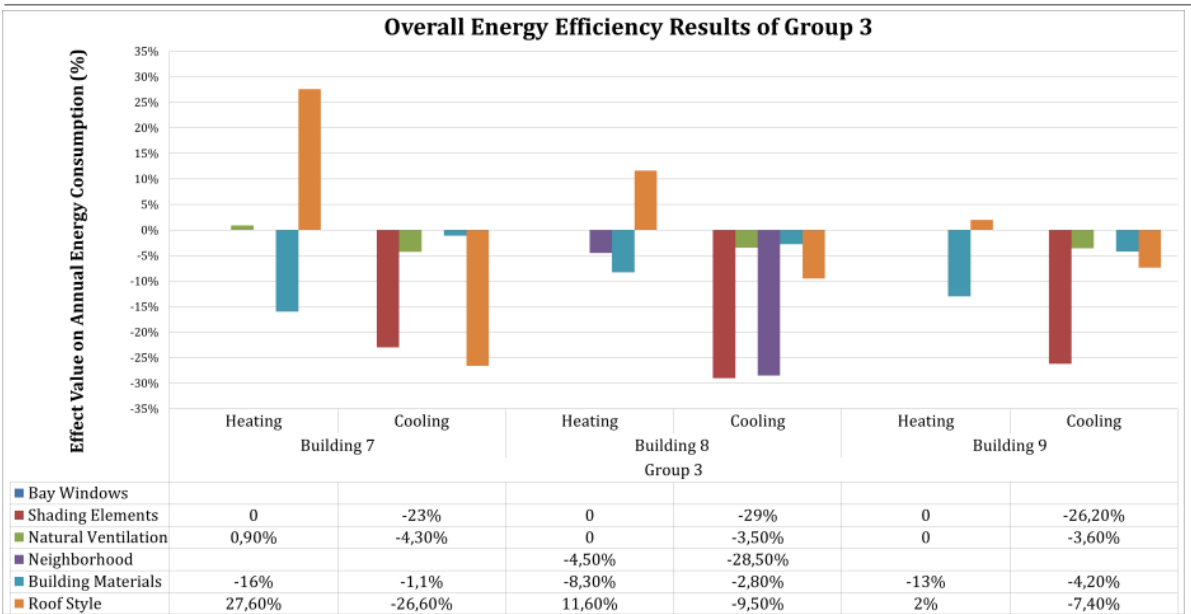

As the ultimate result of the study, "Alaçatı Sustainable Architecture Database Schema" is presented in Table 10 to guide designers that work in Alaçatı province. From this schema, each criterion is not expected to be utilized simultaneously. Rather, they are expected to be used, only if the conditions comply with the specific building conditions. In case of the proposed design data for a criterion cannot be employed, other given options may be applied to achieve an energy-efficient design. The effects on heating and cooling energy demand written under the specialties represent the minimum and maximum values obtained in the present study. The suggestions to the design decisions are listed respectively to the six evaluation criteria.

Table 10. Alaçatı Energy-Efficient Architecture Database Schema

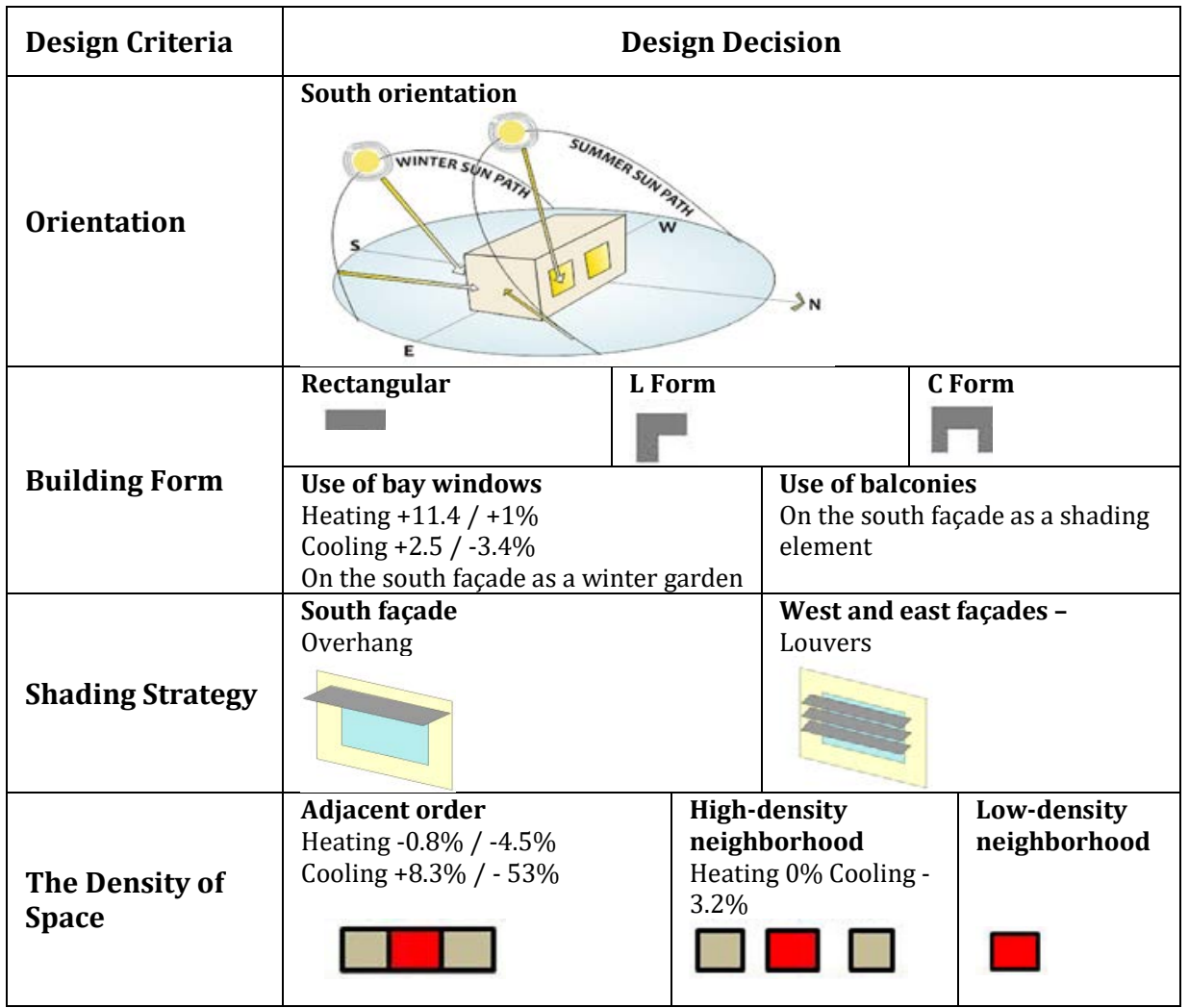




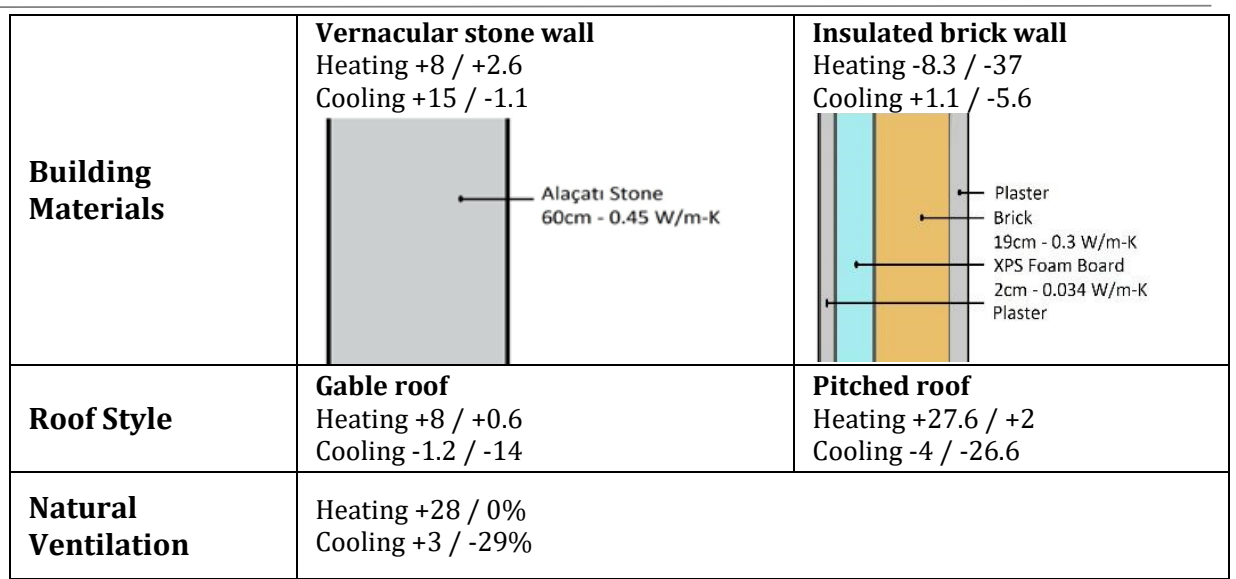

Necessary information about the schema is as follows:

- South orientation is the most appropriate for the new accommodation buildings to be designed in Alaçatı.

- Choosing rectangular, "L" and "C" forms is significant in terms of energy efficiency in the climate of Alaçatı. If the rectangular form is selected, the orientation of the guest rooms should be located in the south. Adjacent walls should be faced to east and south directions if this form is selected in a high-density settlement. Because of its availability to modularity and articulation, rectangular form is the most appropriate for the climate of Alaçatı. If the " $C$ " form is preferred, the orientation of the inner garden should be in the south direction as in Building 9. In case of choosing "L" form, like Building 5, the garden should be oriented towards the south and east.

- In the case of using bay windows, south façades should be preferred to create shading control in summer. Also, the use of bay windows as a sunspace by closing it with a sliding and folding glass separator can contribute to energy efficiency.

- In the case of using semi-open spaces such as balconies, designing them as shading elements on the south façade can be beneficial to reduce the cooling load in the summer.

- Overhang shading in the south façade, louver type shading elements in the west façade should be preferred. The selected shading elements should be operable so that they can be canceled in winter and activated in summer by occupants.

- Preference of stone cladding on the insulated brick wall is the most suitable choice for adaptation to the traditional texture and reducing heating and cooling load.

- It is significant to create an insulated thermal buffer space between the roof and ceiling.

- Windows should be located on the south and north sides to provide cross ventilation since natural ventilation is for energy efficiency. 
- Around the buildings, deciduous trees should be preferred for the southern side, and evergreen trees should be considered in the western and eastern sides.

- Guest rooms should be located in the south direction, while less occupied spaces should be placed in the west and east directions. Building entrances should be preferred in the north direction.

\section{Implementation and the Impact of the Results}

The results showed the influences of the inherited specialties of vernacular architecture on building energy efficiency. Accordingly some properties are very significant in a positive manner, while others affect negatively, or do not have any influence on the energy demand by heating and cooling. Thus, the idea of "vernacular buildings and their design principles are always sustainable" alleged by the studies in the literature is not correct in every case.

The Alaçatı Energy-Efficient Architecture Database Schema, as the outcome of the results of the present study, indicates suggestions to be implemented on the new accommodation building designs in Alaçatı, in order to achieve energy efficiency. The given instructions of this schema are anticipated to contribute to the architects that practice in the traditional urban texture of Alaçatı.

The evaluation method of the study is a potential template for future research in the other tourism centers with vernacular architecture specialties. In terms of sustaining the vernacular features and energy efficiency in the tourism centers, the present study highlights an exemplary endeavor.

\section{CONCLUSIONS AND RECOMMENDATIONS}

The study focuses on the energy efficiency characteristics of accommodation buildings in Alaçatı. Concerning that, the buildings were evaluated in three groups, which are "Accommodation buildings converted from vernacular houses of the area", "New accommodation buildings designed in the style of vernacular houses", "Accommodation buildings with different architectural styles". Three accommodation buildings with different orientations, locations, and form specialties for each group were determined as the nine sample buildings of the study. The case buildings were evaluated regarding the checklist that contains the criteria of building form, shading strategy, natural ventilation, the density of space, building materials, and roof style.

The effects of the energy-efficient architecture criteria on annual heating and cooling demand were attained by building energy modeling. The results of the energy demand effects were presented comparatively between and within the case building groups. According to the evaluation "Alaçatı Energy-Efficient Architecture Database Schema" was 
constituted for the new buildings to be designed in the area by listing the most suitable properties.

The method of the current study gives the possibility to measure the effects of the characteristics of vernacular architecture. Unlike the other studies in the literature that introduce energy-efficient architecture features of vernacular buildings, the current study evaluated the effects of the components' portions on total annual heating and cooling load (Anna-Maria, 2009; Dili et al., 2010; Fernandes \& Mateus, 2012; Manzano-Agugliaro et al., 2015). In contrast with other studies, the present study showed that some features of vernacular architecture, such as vernacular building materials and bay windows, are not energyefficient. However, it was observed that roof style, the density of space, natural ventilation, and shading strategy principles of vernacular buildings decrease heating and cooling load effectively (Alzoubi \& Almalkawi, 2019; Bencheikh \& Bederina, 2020; Gou et al., 2015; Meiting \& Linxue, 2019; Michael et al., 2017; Mohammadi et al., 2017).

Tourism of Alaçatı keeps growing by diversifying. Consequently each year the population of visitors increases. In this context, it is inevitable that both in Alaçatı and its developing areas more accommodation buildings will be constructed. The suggestions of the "Alaçatı EnergyEfficient Architecture Database Schema" will provide both the continuity of the vernacular specialties and reduction of the energy demand in a passive manner. Thus, the authenticity of the Alaçatı vernacular architecture will be visually sustained, while the energyefficient and climate-responsive specialties of the all groups of the buildings are employed.

The results of the study are expected to guide the new studies that focus on the tourism of Alaçatı and its continuity. Moreover, it is envisaged that the study can provide data and a model for further studies related to accommodation buildings in different tourism centers. Determination and comparison of the energy-efficient architecture decisions in Alaçatı and other tourism centers that have different climate conditions are of significance for further studies.

\section{ACKNOWLEDGEMENTS}

This study was adapted from the author's master thesis entitled "Investigation of Accommodation Buildings in Alaçatı in Terms of Climate Responsivity and Sustainable Architecture", supervised by Prof. Dr. Şefika Gülin Beyhan at Süleyman Demirel University.

\section{CONFLICT OF INTEREST}

There is no conflict of interest.

\section{FINANCIAL DISCLOSURE}

The research was supported financially by Süleyman Demirel University Scientific Research Projects Coordination Unit, Isparta, Turkey (Project Number: 06722-YL-16). 


\section{ETHICS COMMITTEE APPROVAL}

Ethics committee approval was not required for this article.

\section{LEGAL PUBLIC/PRIVATE PERMISSIONS}

In this research, the necessary permissions were obtained from the relevant participants (individuals, institutions, and organizations) during the survey.

\section{REFERENCES}

Alanne, K., Söderholm, N., Sirén, K., \& Beausoleil-Morrison, I. (2010). Techno-economic assessment and optimization of Stirling engine microcogeneration systems in residential buildings. Energy Conversion and Management, 51(12), 2635-2646. https://doi.org/https://doi.org/10.1016/j.enconman.2010.05.029

Alzoubi, H. H., \& Almalkawi, A. T. (2019). A comparative study for the traditional and modern houses in terms of thermal comfort and energy consumption in Umm Qais city, Jordan. Journal of Ecological Engineering, 20(5), 14-22. https://doi.org/10.12911/22998993/105324

Anna-Maria, V. (2009). Evaluation of a sustainable Greek vernacular settlement and its landscape: Architectural typology and building physics. Building and Environment, 44(6), 1095-1106.

Balbay, A. (2017). Architectural Projects Archive of Architect Ayșe Balbay.

Baweja, V. (2014). Sustainability and the Architectural History. Enquiry The ARCC Journal for Architectural Research, 11(1), 12. https://doi.org/https://doi.org/10.17831/enq:arcc.v11i1.207

Bencheikh, D., \& Bederina, M. (2020). Assessing the duality of thermal performance and energy efficiency of residential buildings in hot arid climate of Laghouat, Algeria. International Journal of Energy and Environmental Engineering, 11(1), 143-162. https://doi.org/10.1 007/s40095-019-00318-z

Bennetts, H., Radford, A., \& Williamson, T. (2003). Understanding sustainable architecture. Taylor \& Francis. https://doi.org/https://d oi.org /10.4324/9780203217290

Bodach, S., Lang, W., \& Hamhaber, J. (2014). Climate responsive building design strategies of vernacular architecture in Nepal. Energy and Buildings, 81, 227-242. https://doi.org/https://doi.org/10.1016 /j.enbuild.2014.06.022

CCelik, E. (2010). Butik otellerin Alaçatı örnekleri üzerine analizi. Selçuk Üniversitesi Fen Bilimleri Enstitüsü.

Climate: Alaçatı. (2017). No Title. https://tr.climatedata.org/asya/tuerkiye/izmir/alacatı-837763/

Dili, A. S., Naseer, M. A., \& Varghese, T. Z. (2010). Passive control methods of Kerala traditional architecture for a comfortable indoor environment: comparative investigation during various periods of rainy season. Building and Environment, 45(10), 2218-2230. https://doi.org/https://doi.org/10.1016/j.buildenv.2010.04.002 
Durmuş Arsan, Z. (2003). A Critical View of Sustainable Architecture in Turkey: A Proposal for the Municipality of Seyrek. İzmir Institute of Technology.

Durmuş Arsan, Z. (2008). Türkiye'de sürdürülebilir mimari. Mimarlık Dergisi, 340, 21-30. http://www.mimarlikdergisi.com/index.cfm?sayfa= mimarlik\&DergiSayi $=290 \&$ RecID $=1701$

Energy Plus. (2017). Weather Data by Location - EnergyPlus. https://energyplus.net/weather-

location/europe_wmo_region_6/TUR//TUR_Izmir.172180_IWEC

Eyüce, A. (2007). LEARNING FROM THE VERNACULAR: Sustainable Planning and Design. Open House International, 32(4).

Fernandes, J. E. P., \& Mateus, R. (2012). Energy efficiency principles in Portuguese vernacular architecture. Conference: BSA 2012: 1st International Conference on Building Sustainability, 561-572.

Gezgin, I. (2007). Tarih Boyunca Çeșme. Sel Publishing.

GhaffarianHoseini, A., Dahlan, N. D., Berardi, U., GhaffarianHoseini, A., Makaremi, N., \& GhaffarianHoseini, M. (2013). Sustainable energy performances of green buildings: A review of current theories, implementations and challenges. Renewable and Sustainable Energy Reviews, 25, 1-17. https://doi.org/https://doi.org/10.1016/j.rser.201 3.01 .010

Google Earth. (2017). Sattellite Views.

Google Earth. (2018). Sattellite Views.

Gou, S., Li, Z., Zhao, Q., Nik, V. M., \& Scartezzini, J. L. (2015). Climate responsive strategies of traditional dwellings located in an ancient village in hot summer and cold winter region of China. Building and Environment, 86, 151-165. https://doi.org/10.1016/j.buildenv.201 4.12.003

İnce, İ. (2013). Urban design toolkit for creative place-making and cultural tourism: The case of Alaçatı. İzmir Institute of Technology.

KGCArchitecture, S. (2017). Architectural Projects Archive of KGC Architectural DesignOffice.

Koca, G. (2019). Evaluation of traditional Sirince houses according to sustainable construction principles. Iconarp International Journal of Architecture and Planning, 7(1), 30-49. https://doi.org/doi:http://dx. doi.org/10.15320/ICONARP.2019.65

Lane, B. (1994). Sustainable rural tourism strategies: A tool for development and conservation. Journal of Sustainable Tourism, 2(1-2), 102-111. https://doi.org/10.1080/09669589409510687

Liu, J., Hu, R., Wang, R., \& Yang, L. (2010). Regeneration of vernacular architecture: new rammed earth houses on the upper reaches of the Yangtze River. Frontiers of Energy and Power Engineering in China, 4(1), 93-99. https://doi.org/DOI: 10.1007/s11708-010-0002-4

Manzano-Agugliaro, F., Montoya, F. G., Sabio-Ortega, A., \& García-Cruz, A. (2015). Review of bioclimatic architecture strategies for achieving thermal comfort. Renewable and Sustainable Energy Reviews, 49, 736755. https://doi.org/DOI: 10.1016/j.rser.2015.04.095 
Meiting, H. E., \& Linxue, L. I. (2019). Form Follows Environmental Energy: Ecological Heat In Contemporary Vernacular Architecture. E3S Web of Conferences, 101, 2003. https://doi.org/10.1051/e3sconf/ 201910102003

Michael, A., Demosthenous, D., \& Philokyprou, M. (2017). Natural ventilation for cooling in mediterranean climate: A case study in vernacular architecture of Cyprus. Energy and Buildings, 144, 333-345. https://doi.org/10.1016/j.enbuild.2017.03.040

Mohammadi, A., Saghafi, M. R., Tahbaz, M., \& Nasrollahi, F. (2017). Effects of vernacular climatic strategies (VCS) on energy consumption in common residential buildings in southern Iran: The case study of Bushehr city. Sustainability (Switzerland), 9(11). https://doi.org/ $10.3390 /$ su 9111950

Nguyen, A. T., Truong, N. S. H., Rockwood, D., \& Tran Le, A. D. (2019). Studies on sustainable features of vernacular architecture in different regions across the world: A comprehensive synthesis and evaluation. Frontiers of Architectural Research, 8(4), 535-548. https://doi.org/10 .1016/j.foar.2019.07.006

Rasulo, M. (2003). Vernacular architecture related to the climate in the mediterranean basin: A lesson we should learn. 27, 177-188.

Rubel, F., \& Kottek, M. (2010). Observed and projected climate shifts 1901-2100 depicted by world maps of the Köppen-Geiger climate classification. Meteorologische Zeitschrift, 19(2), 135-141.

Santamouris, M., Papanikolaou, N., Livada, I., Koronakis, I., Georgakis, C., Argiriou, A., \& Assimakopoulos, D. N. (2001). On the impact of urban climate on the energy consumption of buildings. Solar Energy, 70(3), 201-216. https://doi.org/https://doi.org/10.1016/S0038-092X(00)0 0095-5

Scott West, P. E., BEAP, B., Demba Ndiaye, P. H. D., \& BEMP, P. E. (2019). Energy Simulation Aided Design for Buildings. ASHRAE Journal, 61(12), $20-26$.

Seymen, S. (2010). Çitoğlu Evi Tash Mahal Oteli. Ege Mimarlık, 72(1), 3841.

Seymen, S. (2017). Architectural Projects Archive of Salih Seymen Architectural Office.

Singh, M. K., Mahapatra, S., \& Atreya, S. K. (2009). Bioclimatism and vernacular architecture of north-east India. Building and Environment, 44(5), 878-888. https://doi.org/https://doi.org/10.1016/j.build env.2008.06.008

Terim, B. (2011). Climatic Considerations in Traditional Built Environments: the Effect of Natural Ventilation on Thermal Comfort in AlaçatiIzmir, Turkey. February.

\section{Resume}

Ali Berkay Avcl is a PhD student and research assistant in Izmir Institute of Technology, Department of Architecture. He received his BSc degree from İzmir Institute of Technology, Faculty of Architecture, Department of Architecture in 
2012. He received his master's degree in Süleyman Demirel University, Faculty of Architecture, Department of Architecture in 2018. He keeps conducting researches in the topics of passive design strategies, thermal comfort, and energy efficiency in architecture.

Şefika Gülin Beyhan is a professor doctor and the head master of Department of Architecture of Süleyman Demirel University. She was graduated from Mimar Sinan Fine Arts University, Department of Architecture. She received her MSc and PhD degrees from Istanbul Technical University, Faculty of Architecture, Department of Architecture. She has research articles, book chapters, conference papers on the topics of tourism buildings, sustainable tourism planning, sustainable architecture, architectural and urban design studies, modern architecture, and cultural studies in architecture. 